UDC 347.1

DOI https://doi.org/10.32849/2663-5313/2021.9.05

Roman Pozhodzhuk,

PhD in Law, Senior Researcher, Senior Research Fellow, Academician F. H. Burchak Scientific Research Institute of Private Law and Entrepreneurship of National Academy of Law Sciences of Ukraine, 23a, Raievskyi street, Kyiv, postal code 01042, Roman Pozhodzhuk@ukr.net

ORCID: orcid.org/0000-0002-6414-4797

Pozhodzhuk, Roman (2021). Specificity of consumer protection in contractual obligations. Entrepreneurship, Economy and Lawe, 9, 31-36, doi: https://doi.org/10.32849/2663-5313/2021.9.05

\title{
SPECIFICITY OF CONSUMER PROTECTION IN CONTRACTUAL OBLIGATIONS
}

Abstract. The aim of the article is a scientific and legal analysis of the relations of consumer protection in contractual obligations in modern conditions and a focus on the specificities of such protection. Results. The article provides a scientific and legal analysis of the relations between the protection of the rights of natural persons - consumers - in contractual obligations in modern conditions and highlights their specificities. The provisions of the current legislation are analysed, as well as the main doctrinal approaches to understanding consumer contractual obligations and protection of consumers as parties to them. The study highlights that consumer relations, despite their civil nature, objectively require State intervention to protect the more vulnerable side of these relations. However, the author argues that this intervention does not imply that such relations are of public law, but they should be considered as of private law. The consumer contract as the basis for consumer contractual obligations is underlined. For example, it is proved that a consumer contract organically integrates the limitations on freedom of contract of civil-law obligations due to its specificity. The author considers that freedom of contract in consumer relations undergoes transformation in modern conditions (subject to some limitation as compared to classical understanding) in order to create an effective balance between the interests of a strong and a weak party to a contractual relationship. Conclusions. It is argued that civil law obligations arising under consumer contracts have their own specificity, determined by their objective and the parties. In addition, it is argued that enhanced consumer protection in consumer relations should be considered an integral and organic part of them, and not merely an additional measure on the part of the State. Finally, the author grounds the increased protection of individuals in consumer contractual relations and the need for State intervention in such relations due to the consumer's natural rights and objective vulnerability to the business entity.

Key words: obligations, consumer, consumer protection, balance of interests of parties.

\section{Introduction}

In recent decades, the commercial sector undergoes evolution, globalization and liberalization due to its technological development, digitization and internationalization. Obviously, this is a certain development of social relations, which quite effectively facilitates cross-border trade and access to goods, works and services for consumers from all over the world. As a result, consumers have more opportunities to obtain goods, jobs or services. For example, consumers ordering certain goods with the help of the latest technologies (smartphone, tablet, etc.) via the Internet save a lot of time for shopping, moreover, being able to receive delivery of such goods to a certain place. However, despite the positive aspects of this development, a corresponding increase in consumer insecurity as a weaker party to the relations should be emphasised. Therefore, considering that the development of consumer relations actually leads to their transformation, new research and rethinking of previous approaches to their understanding are required.

The aim of the article is a scientific and legal analysis of the relations of consumer protection in contractual obligations in modern conditions and a focus on the specificities of such protection.

Consumer law is predominant in the regulatory mechanism for private law relations involving a natural person who purchases a product for private purposes without the intention of making a profit. A large part of the consumer's needs is vital (food, water, medicine, utilities, etc.) and the individual is actually dependent on the economic unit that satisfies such needs and does not always have a choice. Therefore, consumer relations, despite their civil nature, objectively require State intervention to protect the more vulnerable side of these relations. At 
the same time, it should be noted that such intervention does not make these relations public.

Consumer law applies to a natural person since the occurrence of contractual obligation or at the pre-contractual stage. Therefore, safeguard and protection of consumer rights should be considered in relation to contractual obligations. For example, under part 1of article 509 of the Civil Code of Ukraine 435-IV of 16 January 2003 (hereinafter referred to as the CC), an obligation shall be a legal relation where one party (a debtor) shall be obliged to perform an action (to transfer property, to do a job, to render service, to pay money etc.) to the benefit of the other party (a creditor) or to abstain from a certain action (negative obligation), while the creditor shall have the right to claim from the debtor to fulfil his obligation. One of the grounds for civil obligations is a contract.

Contractual obligation is a legal relationship in personam between legally equal and proprietary autonomous persons, arising on the grounds of a concluded contract, which expresses their common will to achieve civil results of a pecuniary or non-pecuniary nature, that arises in case of some debtor's actions in a manner consistent with the creditor's claim and does not affect the rights and legitimate interests of the third persons, non-parties to this legal relationship (Sibilov, 2003).

2. Scientific approaches to defining the concept of "freedom of contract"

As a general rule, civil obligations shall arise on the basis of one of the fundamental pillars of civil law, that is, freedom of contract (part 3 of article 6; part 1of article 627 of the CC of Ukraine)

In this context, S.A. Perebny has formulated the doctrinal definition of freedom of contract rather succinctly. For example, the author considers that freedom of contract is inherent in civil relations and is recognized and guaranteed by the civil legislation of Ukraine by their ability to independently shape and express their will to make rules of conduct (Pohribnyi, 2009, p. 89). Therefore, in accordance with the principle of freedom of contract, no one may be compelled to enter into civil relations, to choose a counterparty or to define the terms of a contract.

Obviously, as a general civilizational principle, freedom of contract is extremely important in contractual relations, but such freedom cannot be unlimited. For example, according to para. 2 of part 3 of article 6 of the CC of Ukraine, the parties to a contract may not deviate from the provisions of civil law unless expressly specified in these regulations as well as in the event that mandatory nature of the provisions of the civil law results from their content or the substance of relations between the parties. However, under part 2 of article 627 of the CC of Ukraine, contracts involving a natural person, a consumer, take into account the requirements of consumer protection legislation. Consequently, these provisions reveal that, in certain cases and for a reasonable purpose, freedom of contract may be limited by peremptory provisions of law.

However, A. Osetynska argues that the CC of Ukraine (article 627) proclaims the principle of freedom of contract, but when concluding consumer contracts, the formation of their terms and conditions is subject to considerable restrictions, as both the procedure for concluding and developing the terms of the contract shall be determined primarily by the peremptory provisions of consumer protection law, moreover, in the manner that provides consumers with privileged terms and establishes additional responsibilities for the entrepreneur. Moreover, specificities of consumer protection imply domination of special methods of protection over the generally civil ones established by the CC of Ukraine (article 16) (Osetynska, 2006, p. 93). T.Ya. Skhab-Buchynska argues that the restriction of freedom of contract may be established in law provisions, as well as any other legal restrictions, and concludes that the proliferation of consumer contract is one of the legal instruments by which the legislator extends or narrows freedom of contract (Skhab-Buchynska, 2017).

In our opinion, consumer contracts do not imply that freedom of contract principle is "substantially limited" or "narrowed," but rather that the principle of freedom of contract in consumer contracts differs in expression from the classical understanding of freedom of contract. Nowadays, given the globalization of consumer relations and the increasing status of consumers in world markets, freedom of contract in its fundamental sense is changing. That does not mean it has lost its historical identity. Rather it implies that freedom of contract in consumer relations is transformed (subject to a certain limitation as compared to classical understanding) in order to effectively balance between the interests of a strong and a weak party to a contractual relationship. In other words, it concerns: 1) freedom of contract in commercial relations and 2) freedom of contract in consumer relations (Pozhodzhuk, 2020).

Therefore, freedom of contract in consumer relations takes into account reasonable intervention in a civil law relationship by the State in order to protect a more vulnerable part to that relationship. It is the dual nature of freedom of contract that enables to fully cover the legal and regulatory mechanism for consumer relationship by peremptory provisions of private 
law rather than public law. The identification of contractual freedom in consumer relations entails that it is already limited, as it is well established for this relationship, rather than that freedom of contract (in the classical sense) is constantly restricted in consumer relations.

With regards to the doctrinal approaches to the consumer contract, V.Ya. Horblianskyi argues that to classify contracts, including the provision of services, as consumer ones, consideration should be given to the combination of two obligatory elements, namely, the parties and the purpose for which the contract is concluded. The parties are, on the one hand, the customer, a natural person, and, on the other hand, the executor, an entrepreneur, who has the necessary legal personality. The purpose of the contract is to meet a personal need which is not related to business (Horblianskyi, 2016). Similarly, A.V. Fedoronchuk argues that the main criteria for classifying a civil contract as a consumer one are, first and foremost, the specific parties and the special purpose for which the contract is concluded. If the party to the contract is a natural person concluding it for personal (domestic) use, the contract can be classified as a consumer one (Fedoronchuk, 2015). However, we argue that the consumer contract, taking into account its specific parties, also has a specific purpose, which is not only to satisfy the personal needs of the consumer. For example, the purpose of a business entity that sells goods, renders services or performs work in favour of an individual is to make a profit, and the purpose of the consumer is to satisfy personal needs. Therefore, such different purposes of the business entity and the natural person-consumer, though aimed at satisfying the interests of both parties, make the purpose of the consumer contract specific.

A modern civil regulatory mechanism governing contractual relations involving consumers should be based on a balanced combination of mutually beneficial (mutually conditioned) interests of consumers and entrepreneurs engaged in the sale of goods, performance of works, rendering services (Bogdan, 2015). For example, civil liability law regulates the basic relationship between the natural person and the consumer. Consumer law, as part of civil law, regulates such relations on the basis of their special nature and the status of a natural person. This shows some symbiosis and synergy. At the same time, the specificity of consumer law is in the use of peremptory provisions in regulating these relations.

The issues of State interference in private law relations have been studied repeatedly by representatives of foreign legal science. For example, Professors L.S. Sealy and R.J.A. Hooley argue that it is important to gain some insight into the relationship between consumer law and commercial law. Some consider consumer law as an application of general commercial law principles in a specific context, although they are largely amended by special consumer legislation (Reynolds, 1982, pp. 93-110). But the differences between the two seem far more fundamental than this approach envisages.

While commercial law deals with transactions in which both parties interact in the course of business, consumer law primarily deals with transactions between ordinary natural persons (consumers) and those who provide goods and services on a commercial basis. While commercial law is based on the assumption that entrepreneurs have roughly equal bargaining power, consumer law provides that the consumer and the business enterprise are economically unequal. In addition, when commercial law is beneficial to businessmen to regulate their own affairs through commercial turnover, such turnover is only peripheral in consumer transactions. These fundamental differences in philosophy mean that while commercial law is not interventional but rather essentially pragmatic in nature, consumer law interferes with contracts between consumers and business suppliers and, in fact, is an instrument of social policy (Sealy, Hooley, 2009, p. 16).

In this context, V.I. Obraztcova argues that the focus of the State and society on the protection and defence of the rights and interests of consumers derives from the importance of the protection and safeguard of those rights and interests, and the need to ensure social stability and the political security of the State (Obraztcova, 2018). We advocate this perspective since the appropriate degree of protection and safeguard of consumers' rights actually results in ensuring the rights and freedoms of people as society in general, thus achieving the level of law-based State. And in accordance with the constitutional maxim, provided for by Article 1 of the Basic Law of the State, Ukraine is a sovereign and independent, democratic, social and law-based State.

3. Specific protection of consumer as parties to contractual obligations

However, according to an apt statement by Professor O. Bar-Gill, natural persons make mistakes. They suffer from imperfect information and imperfect rationality, and therefore may fail to make choices that maximize their preferences. Few people question the truth of this proposition. Even the most insistent critics of behavioural economics recognize that people "often make serious mistakes in deciding important matters" (Epstein, 2006). The question is not whether people make mistakes. Sure, 
they do. The question is whether these mistakes merit legal intervention (Bar-Gill, 2008).

According to the Organization for Economic Cooperation and Development, consumer laws, policies and practices limit fraudulent and misleading and unfair commercial conduct. Such protection is necessary to build consumer confidence and to establish a more balanced relationship between business and consumers in commercial transactions (The Recommendations of the OECD Council Concerning Guidelines for Consumer Protection in the Context of Electronic Commerce, 1999). At the same time, according to S.Yu. Baranov, the State regulatory mechanism for relationship involving consumers through special consumer protection legislation, which partially restricts the civil rights of consumer counterparts (sellers, producers, performers), along with freedom of business, is one of the internal economic functions of the State (Baranov, 2012). Therefore, the proper protection and safeguard of the rights of the individual results in the protection and safeguard of the rights of the entire society.

With regards to the essence of consumer relations and the need for State intervention in such relations to properly protect and safeguard consumers' rights in the contractual obligations, the Constitutional Court of Ukraine stated in Decision 15-rp/2011 of November 10, 2011:

"The Constitutional Court of Ukraine also proceeds from the fact that the State contributes to ensuring the population's consumption of quality goods (works and services), to increasing the well-being of citizens and to the general level of confidence in society. However, the consumer generally objectively lacks the knowledge necessary to make the right choice of products (works, services) from the market and to evaluate contracts for their acquisition, which often are a blank or other standard form (part 1 of article 634 of the Code) (435-15). Therefore, there is a risk for the consumer to be mistaken, or even misled, in purchasing inappropriate credit services. Hence, the State provides special protection to the weaker party to economic relations, as well as the de facto rather than formal equality of the parties to civil relationship, by defining the specificities of contractual legal relations in the field of consumer finance and limiting the principle of freedom of contract. This is done by establishing a special procedure for concluding civil contracts for consumer credit, challenging them, controlling the content and allocating responsibilities between the parties to the contract. In this way, the State simultaneously protects the bona fide seller of goods (works, services) from possible abuse by consumers" (Decision of the Constitutional Court of Ukraine in the case on the constitutional appeal of citizen Stepanenko Andriy
Mykolayovych regarding the official interpretation of the provisions of paragraphs 22, 23 of Article 1, Article 11, part eight of Article 18, part three of Article 22 of the Law of Ukraine "On Consumer Protection" with the provisions of the fourth part of Article 42 of the Constitution of Ukraine (case on protection of the rights of consumers of credit services)).

In this Decision, the Constitutional Court of Ukraine stated quite unequivocally that in consumer finance relations: 1) the consumer is the weaker party to economic relations; 2 ) the de facto equality of the parties in such civil relationship are ensured by State interference in these relations. Therefore, given that consumer finance relations are essentially consumer-oriented, this conclusion can be extrapolated to consumer relations in general.

Furthermore, the doctrine of civil law covers similar considerations. For example, according to V.V. Bogdan, a legal balance of the interests of the parties should be achieved, on the one hand, by granting additional ("special") rights to the consumer, their enhanced protection, on the other hand, should not encourage the abuse of the rights granted to them by law in order to exploit their priority position with bad faith (Bogdan, 2015).

Moreover, it should be noted that the Decision of the Constitutional Court of Ukraine vividly illustrates the consideration of the interests of both parties to the consumer contract and not only of the consumer. Such perspective is appropriate, since State intervention in consumer relations along with protection of the natural person shall not allow that person to abuse the right provided. Therefore, State intervention shall be based on a fair balance of interests among the parties to those contractual obligations.

With regard to enhanced consumer protection in contractual obligations, the focus should also be on the direct link between such protection and the consumer rights of an individual According to A.V. Rabinovych, the fundamental and indispensable manifestation of every human being's existence is its consumption of various pecuniary and non-pecuniary (spiritual, social) goods, that is, its consumer activities. Perhaps, it is not an exaggeration to say that the existence of people is primarily their consumption. Without engaging in a particular consumer activity, no one can live and exist. The ability to engage in consumer activities is reflected, inter alia, in the concept of consumer rights. These rights (abilities) depend primarily on the level of social development achieved, economic, social, spiritual and so forth. After all, a person can consume only those goods that are produced in the process of social production (both pecuniary and non-pecuniary). Consequently, 
these abilities are generally social (socio-natural) in origin. In other words, they are generally social ("natural") consumer human rights (Rabinovych, 2007).

Although advocating the idea of natural consumer rights, we argue that the protection of such rights of the consumer as a party to contractual obligations should be based on providing the individual, as a weak party to the consumer contract, with the priority to be protected. Therefore, the author agrees with V.J. Horblianskyi that the possibility of a consumer contract being concluded by an entrepreneur or a legal person to meet the personal needs of its participants belies the principle of a "weak party" of the contract. As a legally aware party to contractual relations, legal entities and entrepreneurs exercise the right to protection, not applying the provisions of Law of Ukraine 1023-XII "On the Protection of Consumers' Rights” of May 12, 1991, and if these parties are classified as consumers, this may lead to abuse of their rights as consumers (Horblianskyi, 2016).

\section{Conclusions}

The literature review and analysis of current legislation and court practice enable to conclude that the natural rights of consumers and their objective vulnerability to the business entity are basic factors that determine the specificity of consumer protection of individuals in contractual obligations. This specificity implies that the state intervenes in consumer contractual relations with a view to protecting rights of natural persons as a vulnerable party. Moreover, the different interests of both parties to the contract are considered in order to ensure a fair balance of such interests.

\section{References:}

Baranov, S.Iu. (2012). Grazhdansko-pravovye sredstva okhrany prav potrebitelei [Civil Law Means of Consumer Protection]. Extended abstract of candidate's thesis. Saratov. (in Russian).

Bar-Gill, Oren (2008). The behavioral economics of consumer contracts. Minnesota law review. 92. 749-802. URL: https://www.minnesotalawreview.org/wp-content/uploads/2011/08/BarGill_final.pdf (in English).

Bogdan, V.V. (2015). Grazhdansko-pravovoe regulirovanie zashchity prav potrebitelei v sovremennoi Rossii : problemy teorii i praktiki [Civil law regulation of consumer protection in modern Russia: problems of theory and practice]. Doctor's thesis. Kursk. (in Russian).

Fedoronchuk, A.V. (2015). Dohovir prokatu [Rental agreement]. Candidate's thesis. Ivano-Frankivsk: PNU im. V. Stefanyka, yurydychnyi instytut (in Ukrainian).

Horblianskyi, V.Ia. (2016). Dohovir pro nadannia posluh yak riznovyd spozhyvchoho dohovoru [Service contract as a kind of consumer contract]. Naukovyi visnyk Uzhhorodskoho natsionalnoho universytetu - Scientific Bulletin of Uzhhorod National University, 39 (1), 46-49. (in Ukrainian).

Obraztcova, V.I. (2018). Grazhdansko-pravovye problemy samozashchity kak formy zashchity prav potrebitelei [Civil law problems of self-defense as a form of consumer protection]. Problemy ekonomiki i iuridicheskoi praktiki - Problems of economics and legal practice, 5, 195-201. (in Russian).

Osetynska, H.A. (2006). Tsyvilno-pravovyi zakhyst prav spozhyvachiv za zakonodavstvom Ukrainy [Civil law protection of consumer rights under the legislation of Ukraine]. Candidate's thesis. Kyiv. (in Ukrainian).

Pohribnyi, S.O. (2009). Mekhanizm ta pryntsypy rehuliuvannia dohovirnykh vidnosyn u tsyvilnomu pravi Ukrainy [Mechanism and principles of regulation of contractual relations in the civil law of Ukraine]. Doctor's thesis. Kyiv: Kyivskyi natsionalnyi un-t im. Tarasa Shevchenka. (in Ukrainian).

Pozhodzhuk, R.V. (2020). Svoboda dohovoru v aspekti spozhyvchykh vidnosyn [Freedom of contract in the aspect of consumer relations]. Pryvatne pravo i pidpryiemnytstvo - Private law and entrepreneurship, 20, 106-111. (in Ukrainian).

Rabinovych, A.V. (2007). Pravo liudyny na hidnyi riven spozhyvannia ta yurydychnyi mekhanizm yoho zabezpechennia $\mathrm{v}$ Ukraini (zahalnoteoretychne doslidzhennia) [The human right to a decent level of consumption and the legal mechanism for its provision in Ukraine (general theoretical study)]. Extended abstract of candidate's thesis. Odesa: Nats. un.-t "Odeska yurydychna akademiia". (in Ukrainian).

Reynolds, F. (1982). The Applicability of General Rules of Private Law to Consumer Disputes' in S Andermann et al (eds) Law and The Weaker Party, 2, pp. 93-110. (in English).

Richard, A. Epstein, Behavioral Economics: Human Errors and Market Corrections, 73 U. CHI. L. REV. 111, 111 (2006) [hereinafter Epstein, Behavioral Economics]. Bar-Gill, Oren. (2008). The behavioral economics of consumer contracts. Minnesota law review. 92. 749-802. URL: https:// www.minnesotalawreview.org/wp-content/uploads/2011/08/Bar-Gill final.pdf (in English).

Rishennia Konstytutsiinoho Sudu Ukrainy u spravi za konstytutsiinym zvernenniam hromadianyna Stepanenka Andriia Mykolaiovycha shchodo ofitsiinoho tlumachennia polozhen punktiv 22, 23 statti 1, statti 11, chastyny vosmoi statti 18, chastyny tretoi statti 22 Zakonu Ukrainy 
«Pro zakhyst prav spozhyvachiv» u vzaiemozviazku z polozhenniamy chastyny chetvertoi statti 42 Konstytutsii Ukrainy (sprava pro zakhyst prav spozhyvachiv kredytnykh posluh) vid 10.11.2011 № 15-rp/2011 [Decision of the Constitutional Court of Ukraine in the case on the constitutional appeal of citizen Stepanenko Andriy Mykolayovych regarding the official interpretation of the provisions of paragraphs 22, 23 of Article 1, Article 11, part eight of Article 18, part three of Article 22 of the Law of Ukraine "On Consumer Protection" with the provisions of the fourth part of Article 42 of the Constitution of Ukraine (case on protection of the rights of consumers of credit services) from 10.11.2011 № 15-рп/2011]. (2011). zakon.rada.gov.ua. Retrieved from https://zakon.rada.gov.ua/ laws/show/v015p710-11 (in Ukrainian).

Sealy, L.S., Hooley, R.J.A. (2009). Commercial law : text, cases, an materials /. - $4^{\text {th }}$ ed. 1325 p (in English).

Sibilov, M. (2003). Dohovirne zoboviazannia ta yoho vykonannia [Contractual obligation and its fulfillment]. Visnyk Akademii pravovykh nauk Ukrainy - Bulletin of the Academy of Legal Sciences of Ukraine, 2-3 (33-34), 414-424. (in Ukrainian).

Skhab-Buchynska, T.Ia. (2017). Obmezhennia svobody u dohovori pro spozhyvchyi kredyt [Restriction of freedom in the consumer loan agreement]. Aktualni problemy vdoskonalennia chynnoho zakonodavstva Ukrainy - Current problems of improving the current legislation of Ukraine, 43, 187-195. (in Ukrainian).

The Recommendations of the OECD Council Concerning Guidelines for Consumer Protection in the Context of Electronic Commerce, 1999. Retrieved from http://www.oecd.org/internet/consumer/34023235.pdf (in English).

\section{Роман Пожоджук,}

кандидат юридичних наук, старший дослідник, старший науковий співробітник, Науководослідний інститут приватного права $і$ підприємництва імені академіка Ф. Г. Бурчака Національної академії правових наук України, вулищя Миколи Раєвського, 23а, Київ, Україна, індекс 01042, Roman Pozhodzhuk@ukr.net

ORCID: orcid.org/0000-0002-6414-4797

\section{СПЕЦИФІКА ЗАХИСТУ ПРАВ СПОЖИВАЧІВ У ДОГОВІРНИХ ЗОБОВ'ЯЗАННЯХ}

Анотація. Метою статті є проведення науково-правового аналізу відносин захисту прав споживачів у договірних зобов'язаннях у сучасних умовах та висвітлення особливостей такого захисту. Результати. У статті здійснюється науково-правовий аналіз відносин захисту прав фізичних осіб - споживачів у договірних зобов'язаннях у сучасних умовах та висвітлюються особливості цих відносин. Проаналізовано положення чинного законодавства, а також основні доктринальні підходи до розуміння споживчих договірних зобов'язань і захисту прав споживачів як їх учасників. Звертається увага на той факт, що споживчі відносини, незважаючи на їхню цивільно-правову природу, усе-таки об'єктивно потребують державної інтервенції з метою захисту більш вразливої сторони цих відносин. При цьому зауважено, що зазначена інтервенція не робить такі відносини публічноправовими, а повинна вважатися складовою частиною приватноправових відносин. Окремо приділено увагу саме споживчому договору як підставі виникнення споживчих договірних зобов'язань. Так, доведено, що споживчий договір унаслідок своєї специфіки органічно інтегрує обмеження свободи договору цивільно-правових зобов'язань. На нашу думку, свобода договору у споживчих відносинах у сучасних умовах трансформується (підлягає певному обмеженню порівняно 3 класичним розумінням) задля створення ефективного балансу інтересів сильної та слабкої сторін договірних відносин. Висновки. Доведено, що цивільно-правові зобов'язання, які виникають на підставі споживчих договорів, мають свою специфіку, зумовлену їхньою метою та суб'єктним складом їх учасників. До того ж стверджується, що підвищений захист прав споживачів у споживчих відносинах варто вважати невід'ємним та органічним їх складником, а не лише додатковим заходом із боку держави. У підсумку зроблено спробу обгрунтувати підвищений захист фізичних осіб у споживчих договірних відносинах і необхідність державної інтервенції в такі відносини природними правами споживача та об'єктивною його незахищеністю перед суб'єктом господарювання.

Ключові слова: зобов’язання, споживач, захист прав споживачів, баланс інтересів сторін. 